\title{
IAMJ
}

INTERNATIONAL

AYURVEDIC

MEDICAL JOURNAL

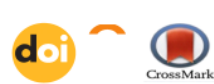

Case Report

ISSN: 2320-5091

Impact Factor: 6.719

\section{A CASE REPORT ON THE ROLE OF PATRAPOTTALI SWEDA IN THE MANAGEMENT OF AVABAHUKA}

\section{$\underline{\text { S.N. Belavadi }}^{1}, \underline{\text { Chaitrika Hosur }}^{2}$}

${ }^{1}$ Professor and HOD, Department of Kayachikitsa, D.G.M Ayurvedic Medical College, Gadag - 582101, Karnataka, India

${ }^{2}$ P.G. Scholar, Department of Kayachikitsa, D.G.M Ayurvedic Medical College, Gadag - 582101, Karnataka, India

Corresponding Author: hosurchaitrika@gmail.com

\section{https://doi.org/10.46607/iamj16p5052021}

(Published online: July 2021)

Open Access

(C) International Ayurvedic Medical Journal, India 2021

Article Received: 25/06/2021 - Peer Reviewed: 03/07/2021 - Accepted for Publication: 04/07/2021

Check for updates

\begin{abstract}
Avabahuka is one of the diseases which involve the neuromuscular system. Pain and restricted movement in the shoulder joint is the main symptom that makes the patient seek the help of physicians. Ayurveda considers this under Vatayadhi. Avabahuka Chikitsa in Ayurveda has good relief for the patients suffering from the disease. A Male patient of age 70 yrs. approached D.G.M Ayurvedic Medical College and Hospital with pain restricted movement and stiffness in the Rt. Shoulder for 6 days and diagnosed as Avbahuka. The patient was subjected to the Patrapottali Sweda along with the Shamana Yogas. After the treatment, the stiffness of the joint was reduced. The patient got moderate relief from the pain. This Keralaiya Chikitsa Paddati is more convenient in relieving the symptoms compared to the modern system of medicine.
\end{abstract}

Keywords: Avabahuka, Patrapottali Stiffness, Restricted movement, Shoulder pain Case report

\section{INTRODUCTION}

Pain is the symptom that alters the day-to-day activities of the person. The Neuromuscular System mainly involves pain pathology which is controlled by the Vata according to the Ayurveda. Shoulder pain is 
the third most common musculoskeletal reason for people to approach physicians. Even though Avabahuka is not mentioned in the Vataja Nanatmaja Vyadhi by Acharya Charaka, Acharya Sushruta and Acharya Vagbhata conclude this under the Vatavyadhi. The Amsa shosha word mentioned by Acharya Charaka is one of the major symptoms of Avbahauka. He also mentioned the Bahusheersha gata vaata ${ }^{1}$ which is almost similar to the Avbahuka. Madhukosha explains two types of Avabahuka one is Vataja, and the Second type is Vata Kaphaja. ${ }^{2}$ Nirukti: Avabahuka composes two words; 'Aval $A p a{ }^{3}$ means Vikrati ${ }^{4}$ or Viyoga (dysfunction) and 'Bahu' means Shoulder. This Nirukti summarizes that the word "Avabahuka "represents 'dysfunction' in the Shoulder joint. Avabahuka is a Disease that mainly affects the shoulder joint (Amsa Sandhi). It is characterized by the morbid Vata Dosha localizing around the Amsa Pradesha and thereby causing Soshana of Shleshmaka Kapha of Amsa bandha ${ }^{5}$ Akunchana of sira occurs at this site because of vata leads to Bahupraspanda Haran. ${ }^{6}$ Its main symptoms are Bahupratispanditahara (Limited range of movements), Vedana (pain), Sthambana (Stiffness) and Sira Akunchana. Avabahuka will manifest due to both Datukshaya as well as Margaavarana. ${ }^{7}$ Both of these will cause vitiation of Vata. In Ayurveda Snehanan, virechana, Vatanulomana, Deepana, Pachana, Niruha and Anuvasana Basti, Nasya, Dhoomapana and Madhura, Aamla, lavana Snigdha ahara is explained as Samanya Chikitsa Siddhanta for Vata Vyadhi. ${ }^{8}$ Ashtanga Hridayakara explain Chiktsa Siddanta for Avabahuka as Nasya and Abhyantara Sneha after food ${ }^{9}$. Navan Nasya and Snehapana are explained as a treatment for Avabahuka. ${ }^{10}$ Sthanika Abhyanga and Patrapottali Sweda are used in this case to get a better result. Patrapottali Sweda ${ }^{11,12}$ refers to the Swedana performed using a bundle of VataKaphahara Patras and it is a form of Ushna Sweda. Among the classics, Sushruta Samhita explains about the Jambira Pottali Sweda while explaining about the Samanya vatavaadi Chikitsa.${ }^{13}$ In Patrapottali pieces of lemons are also used. This is considered one of the most promising treatment techniques followed by the Kerala Ayurveda practice. Objectives: To study the effect of Sthanika abhyanga and Patrapottali Sweda in relieving the symptoms of Avabahuka.

\section{CASE STUDY:}

A male patient of Age 70 years approached the Kayachikitsa Department at D.G.M Ayurvedic College Hospital. OPD no. 20026671. He had pain, stiffness and restricted movement of Rt. shoulder for 6 days. No history of any external trauma to the affected part. No any relevant surgical or medical history. The patient had mild pain in the initial stage and gradually developed stiffness and severity in pain intensity. Shoulder movements become restricted, and the patient develops difficulty in raising the right shoulder. Even after taking painkillers, the patient continued with the same complaints which made him worried about his condition.

Samanya Pareeksha: The patient was well built; ill look was there on his face because of the pain. Gait was normal. His weight was $69 \mathrm{~kg}$ and other parameters are under normal limits.

Ashta sthana Pariksha: Naadi: 86bpm, Mutra Pravrutti-Samyak Pravartana 5-6 times a day and 1 time in night, Mala Pravrutti-Samyak Pravartana 1 time a day, Shabda- Prakruta, SparshaAushnasheeta, Druk - Prakrita, Akriti -Uttama

Srotas Pariksha: Annavaha Srotas- Agnimandya. Mamsavaha Srotas- Sthamba of Dakshina Bahu., Astivaha Srotas- Shoola in Dakshina Bahu

\section{Nidana Panchaka:}

Hetu: Jaravastha, Avyayama, Rooksha ahara seven., Purva Roopa: Alpa vedana in Dakshina Amsa Sandhi, Roopa: Dakshina Amsasandhi shoola, Sthamba and bahupraspandita hara

Samprapti Ghataka: Dosha: Vata and Kaph, Dushya: Maamsa, Medha, Asthi, Majja, Sroto Dushti: Sanga, Udbhvava Sthana- Pakvashaya, Vyakta Sthana- Amsa sandhi, Sadhyasaadyata - krachha sadhya., Vyadhi vyavachhedhana: Avabahuka, Vishwachi, Manya Sthamba 
Examination of Shoulder Joint: ${ }^{12}$

Inspection: Discoloration: Absent, Muscle wasting: Absent, Deformity: Absent, Palpation: Stiffness Present at rt. shoulder joint, Temperature: Absent, Restriction of Movement: Present up to 40 degrees., Investigation: X-Ray - No abnormality detected.
Materials and Method:

Sources of Data: D.G.M Ayurvedic Medical College, Hospital, Gadag, Karnataka

Drug sources: D.G.M Botanical Garden, Gadag, Karnataka

Method of Sampling and Study Design: Simple randomized Single Case study.

Table 1: Showing Materials used in the study:

\begin{tabular}{|c|c|c|c|c|c|c|}
\hline No & Chikitsa & $\begin{array}{l}\text { Duration of } \\
\text { Intervention }\end{array}$ & Dose & Kala & Anupana & Outcome \\
\hline 1. & $\begin{array}{l}\text { Mahayogaraj } \\
\text { Guggulu }\end{array}$ & $1^{\text {st }}$ to 15 Days & $500 \mathrm{mg}$ & $\begin{array}{l}\text { Prataha kaala } \\
\text { and Ratri }\end{array}$ & $\begin{array}{l}\text { Sukoshna } \\
\text { Jala }\end{array}$ & $\begin{array}{l}\text { Shoola Hara and } \\
\text { Vaatakapha Hara }\end{array}$ \\
\hline 2. & Cap. Bonton & $1^{\text {st }}$ to 15 Days & $\begin{array}{l}1 \\
\text { capsule }\end{array}$ & $\begin{array}{l}\text { Prataha Kaala } \\
\text { and Ratri }\end{array}$ & $\begin{array}{l}\text { Sukoshna } \\
\text { Jala }\end{array}$ & Asthiposhaka \\
\hline 3. & $\begin{array}{l}\text { Ashtavarga } \\
\text { Kashaya }\end{array}$ & $1^{\text {st }}$ to $15^{\text {th }}$ Day & $10 \mathrm{ml}$ & $\begin{array}{l}\text { Prataha Kaala } \\
\text { and Ratri }\end{array}$ & Jala & $\begin{array}{l}\text { Vatahara } \\
\text { Vedanasthapana }\end{array}$ \\
\hline
\end{tabular}

\section{Panchakarma Intervention:}

1. Sthanika Abhyanga:

Sthana: To the Dakshina Bahu, Ingredient: Karpooradi Taila.

Benefits: Shoolaprashamana, Vatashamana. Duration: 8 Days

2. Patrapottali Pinda Sweda:

Sthana: To the Dakshina Bahu

Ingredients: Nimba Patra, Arkapatra, Nirgundi Patra, Eranda patra, Dhatura patra, Grated coconut, Lemon,

Haridra, Saindhava Lavana.
Benefits: Shoola prashamana, reduces Sthambana., Duration: 8 Days.

Result: After the 8 days of treatment improvement is seen in the symptoms of the patient. There was moderate relief in the pain. Stiffness was reduced comparatively. The range of movement of the affected shoulder is also increased. Clinical assessments were made from the interrogation and gradation of the scoring pattern.

Table 2: Showing grading before and after treatment.

\begin{tabular}{|l|l|l|l|}
\hline SL.NO & SYMPTOMS & SCORE BEFORE TREATMENT & SCORE AFTER TREATMENT \\
\hline 1. & Pain & 9 (severe) & 6 (Moderate) \\
\hline 2. & Stiffness & 9 (Severe) & 4 (Moderate) \\
\hline 3. & Range Of Movement & 45 degrees & 60 degrees \\
\hline
\end{tabular}




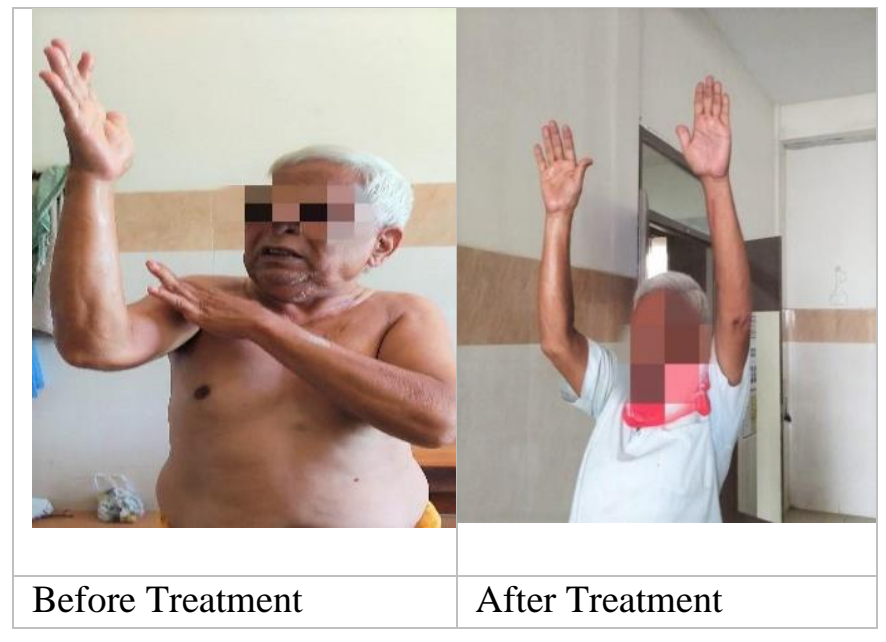

\section{DISCUSSION}

In this case, the Vatavriddhi took place in the patient because of his age, psychological factors and diet regimen. Vriddavastha usually had Vata predominance. Along with this, the Chinta and Shokadi Manasika Hetus are also elevated the Vata in this case. The patient also had a habit of taking more Vatala Aharas. The patient even had a Mandagni. These factors made Vata Vriddhi associated with the Kapha, Sthanasamshraya took place in the Dakshina Bahu. Shoola Sthambadi symptoms manifested because of the above reasons. To reduce these symptoms, Vatakaphahara properties Yogas are used for Shamana. Yogaraja Guggulu has Shoolahara, Brihmhana and Balya properties which are beneficial in reducing the symptoms in this case. The Panchakarma procedure is planned for 7 days. Sthanaika Abhyanga from Dakshina Amsasandhi to Hastha is carried out by using Karpooradi Taila, which has Shoolahara and Vatahara Properties. Patrapottali Sweda is the main line of treatment here. Mainly it is indicated for the Upasthambita Vata Vyadhi. The Patras used in these preparations all have the Vatahara properties. The Lemons used in this are Amlarasa Pradhana, Ushna and Sukshma guna. This helps to reduce the shoola, Sthamba and Bahuoraspandana. Patrapottali Sweda worked with Ushnaguna to stimulate the Sympathetic Nervous System and resulted in vasodilation. Due to the effect of Sara and Sukshma guna of Swedana Dravya, Leena Dosha present in the body gets liquefied and comes out through the micropores. Thus, the symptoms reduce. Within seven days symptoms were reduced to Severe to Moderate. One more sitting of the Patrapottali Sweda or the continuity of the treatment for one more week will be going to reduce the symptoms to a better extent.

\section{CONCLUSION}

'Avabahuka' vyadhi associated with Vata and Kapha dosha can easily manage or be treated with Ayurvedic medicines and Panchakarma procedures like Patrapottali Sweda. It is one of the most promising Keraliya Chikitsa Paddati in the Vatavyadi. The treatment principle is based on the combined effect of heat and medicament. Proper selection of drugs and proper duration of the treatment will cure the disease.

\section{REFERENCES}

1. Agnivesha, Charaka Samhita with Chakrapani Commentary Ayurveda Deepika, Edited by Y.T Acharya, Reprint 2017, Varanasi; Chaukamba Surbharati Prakashana, Chikitsa Sthana, 28 ${ }^{\text {th }}$ Chapter, Shloka No. 98, Page No. 621

2. Madhava, Madhava Nidana with madhukosha Commentary by Vijaya Rakshita, and Shrikantha Datta, Edited by Sudarshana Shastri, Revised $7^{\text {th }}$ edition by Prof. Yadunandana Upadya, Part 1: Chaukamaba Prakashana Varanasi; Reprint 2010. 22 ${ }^{\text {nd }}$ Chapter, Vatavyadhi Nidanam, Shloka No. 65, Page no. 490

3. Monier Williams Sanskrit English Dictionary; $1^{\text {st }}$ edition, oxford university press, Delhi, 2002; page no.96

4. Raja Radhakantade, Shabadakalpadruma, Sanskrit Dictionary, $3^{\text {rd }}$ edition, Varanasi; Cahukamba Sanskrit series; 1996.Page no.97

5. Sushruta, Sushruta Samhita with Nibandha Sangraha Commentary of Dalhanaacharya and Nyatachandrika Vyakya Panjika of sri gayadasa Acharya, Edited by Vaidya Jadavji Trikamji Acharya, Varanasi: Chaukamba Orientalia; Reedited 2014. Nidana Sthana $1^{\text {st }}$ Chapter, Shloka No. 82 Page no.269

6. Vagbhata, Ashtanga Hridaya with Vidyitini Thika by Kaviraja Atridev Gupta, Edited by Vaidya Yadunanadana Upadhyaya, Reprint 2012, Varanasi; Chaukamba Prakashana; Nidhana Sthana $15^{\text {th }}$ Chapter, Shloka no.43, page no,379 
7. M adhava, Madhava Nidana with madhukosha Commentary by Vijaya Rakshita, and Shrikantha Datta, Edited by Sudarshana Shastri, Revised $7^{\text {th }}$ edition by Prof. Yadunandana Upadya, Part 1: Chaukamaba Prakashana Varanasi; Reprint 2010. 22 ${ }^{\text {nd }}$ Chapter, Vatavyadhi Nidanam, Shloka No. 65, Page no. 490

8. Agnivesha, Charaka Samhita with Chakrapani Commentary Ayurveda Deepika, Edited By Y.T Acharya, Reprint 2017, Varanasi; Chaukamba Surbharati Prakashana, Chikitsa Sthana, $28^{\text {th }}$ Chapter, Shloka No. 84-89, Page No. 620

9. Vagbhata, Ashtanga Hridaya with Vidyitini Thika by Kaviraja Atridev Gupta, Edited by Vaidya Yadunanadana Upadhyaya, Reprint 2012, Varanasi; Chaukamba Prakashana; Chikitsa Sthana $21^{\text {st }}$ Chapter, Shloka no.44, page no,571

10. Vagbhata, Ashtanga Sangraha, Sarvangasundari Vyakya Sahita, elaborated by Shri P Lalchandra Shastri and acharya Raghveera Prasad Trivedi, Published by Baudyanath Nagpur, $1^{\text {st }}$ edition 1989; Chikitsa Sthana $28^{\text {th }}$ Chapter Shloka no.32-34, Page no.989

11. Vasant C. Patil, Principles and Practice of panchakarma, Third edition, 2012, Atreya Ayurveda Publications, Ilkal, Karnataka, Swedana Karma, Page No.207

12. Pavana Jairam, Keraliya Chikitsa Paddati, published by Sarada Mahd Eva Iyer, Ayurvedic Educational and Charitable Trust, Tamilnadu, Page n0.199.

13. Sushruta, Sushruta Samhita with Nibandha Sangraha Commentary of Dalhanaacharya and Nyatachandrika Vyakya Panjika of sri gayadasa Acharya, Edited by Vaidya Jadavji Trikamji Acharya, Varanasi: Chaukamba Orientalia;Reedited 2014. Sutra Sthana $12^{\text {th }}$ Chapter, Shloka No. 10 Page no.122

14. Ayurvedic Management in Avabahauka - A case Study, by Khot Jitendra $\mathrm{D}$ and team, Published by International Ayurvedic Medical journal

15. Literature Review of Study of Pinada Sweda and its Modifications by Dr Supriya Ambhore and team, Published by International Journal of Multidisciplinary health Sciences.

\section{Source of Support: Nil}

\section{Conflict of Interest: None Declared}

How to cite this URL: S.N. Belavadi \& Chaitrika Hosur: A Case Report On The Role Of Patrapottali Sweda In The Management Of Avabahuka. International Ayurvedic Medical Journal \{online\} 2021 \{cited July, 2021\} Available from: http://www.iamj.in/posts/images/upload/3055_3059.pdf 